\title{
IMPLEMENTASI GOOD CORPORATE GOVERNANCE SEBAGAI UPAYA MEMINIMALKAN EKSPROPRIASI DALAM MENINGKATKAN KINERJA PERUSAHAAN
}

\author{
Dito Rinaldo \\ Pascasarjana Universitas Padjajaran
}

\begin{abstract}
Good Corporate Governance Implementation In Order To Minimize Expropriation to Increase the Company Performance. The aim of this research is to analyze does good corporate governance mechanism had a good function in order to solve the agents problem in Indonesia such as the ekspropriation to minority share holders through panel data regression. The result of this research is institutional and managerial ownership had a positive influence to MLO but not to NPM. Meanwhile, the institutional ownership had a negative influence to PP, this result has a justification that there had been an expropriation in the company. The managerial ownership variable had a positive influence to $P P$, this result shown that the debt establishment had pushed the company to incrase the income for paying the fixed cost such as interest.
\end{abstract}

Keywords: GCG, panel data regression, expropriation, performance

\begin{abstract}
Abstrak. Implementasi Good Corporate Governance Sebagai Upaya Meminimalkan Ekspropriasi Dalam Meningkatkan Kinerja Perusahaan. Penelitian ini bertujuan untuk mengetahui apakah mekanisme good corporate governance telah berfungsi secara maksimal di dalam mengatasi permasalahan keagenan di Indonesia yaitu ekspropriasi terhadap pemegang saham minoritas, melalui pengujian mekanisme GCG terhadap kinerja perusahaan, dengan menggunakan metode regresi data panel. Berdasarkan hasil penelitian kepemilikan institusional dan kepemilikan manajerial berpengaruh positif pada MLO, tetapi tidak berpengaruh terhadap NPM. Selain berpengaruh pada MLO, kepemilikan insitusional juga berpengaruh negatif terhadap PP, hal ini semakin memperkuat bahwa ekspropriasi terjadi di perusahaan. Variabel kepemilikan manajerial memiliki pengaruh positif dan signifikan terhadap PP. Pengaruh positif dan signifikan leverage terhadap PP, menunjukan keberadaan utang mendorong perusahaan meningkatkan pendapatannya untuk menutupi beban tetap yaitu bunga.
\end{abstract}

Kata kunci: GCG, regresi data panel, ekspropriasi, kinerja 


\section{PENDAHULUAN}

Sebagaimana diketahui bahwa konflik keagenan menjadi salah satu isu sentral dalam pengelolaan perusahaan (corporate finance). Penyebab munculnya konflik tersebut tidak lain adalah karena adanya pemisahan antara kepemilikan dan kontrol (Davis, et.al, 1997), dimana kepemilikan perusahaan terdiri dari sejumlah pemegang saham, dan pengelolaan perusahaan diserahkan kepada manajemen, sehingga menimbulkan kemungkinan manajemen akan bertindak tidak mengedepankan kepentingan pemegang saham, atau manajemen bertindak untuk mengejar kepentingan pribadinya dengan mengorbankan pemegang saham (Ross et. al 2009).

Konflik antara pemilik dan manajemen inilah yang dijelaskan dalam teori keagenan dan dikenal sebagai agency problem (konflik keagenan). Jensen dan Meckling (1976) menyatakan bahwa untuk menekan konflik keagenan dapat dilakukan melalui penerapan good corporate governance (GCG), yang dalam implementasinya menggunakan berbagai mekanisme sebagai kontrol terhadap pengelolaan perusahaan oleh manajemen.

Isu yang berkembang bahwa sebagian besar perusahaan go public di Indonesia masih dimiliki secara mayoritas atau secara dominan oleh keluarga pendiri perusahaan, dan keluarga pendiri ini terlibat dalam manajerial perusahaan. Solomon dan Solomon (2004) menyatakan bahwa di kelompok pelaku bisnis swasta di Indonesia sebagian besar perusahaan adalah perusahaan keluarga. Dengan keadaan demikian maka permasalahan keagenan di Indonesia lebih mengarah pada konflik antara pemegang saham mayoritas yang umumnya adalah keluarga, dengan pemegang saham minoritas. Permasalahan keagenan tersebut tentunya akan mempengaruhi kinerja perusahaan, sehingga membutuhkan mekanisme yang mampu mengatasinya.

Jansen dan Meckling (1976), untuk mengatasi permasalahan keagenan dapat dilakukan dengan penerapan GCG melalui mekanisme-mekanisme GCG, hanya saja dikarenakan konflik keagenan di Indonesia adalah konflik antara pemegang saham mayoritas dan minoritas, maka perlu dilakukan pengujian terhadap mekanisme GCG yang ada diperusahaan, untuk mengetahui apakah mekanisme GCG tersebut efektif atau tidak. 
Berdasarkan permasalahan terjadinya ekspropriasi yang telah dijelaskan pada latar belakang penelitian, maka rumusan masalah dalam penelitian ini adalah: pertama, apakah terdapat pengaruh positif dan signifikankepemilikan institusional terhadap kinerja perusahaan? Kedua, apakah terdapat pengaruh positif dan signifikan kepemilikan manajerial terhadap kinerja perusahaan? Ketiga, apakah terdapat pengaruh positif dan signifikan leverage terhadap kinerja perusahaan. Keempat, apakah terdapat pengaruh positif dan signifikan komisaris independen terhadap kinerja perusahaan?

Berdasarkan latar belakang dan rumusan penlitian, maka tujuan dari penelitian ini adalah untuk mengetahui apakah mekanisme GCG, yaitu kepemilikan institusional, kepemilikan manajerial, leverage, dan komisaris independen, berpengaruh atau terhadap kinerja perusahaan yang diukur menggunakan 4 (empat) perpektif dalam balance scorecard. Oleh karenanya, dapat diketahui mekanisme mana yang efektif meminimalkan ekspropriasi terhadap pemegang saham minoritas.

\section{METODE}

Pada penelitian ini akan digunakan Judgement sampling yaitu teknik penarikan sampel berdasarkan karakteristik yang ditentukan terhadap elemen populasi yang disesuaikan dengan tujuan dan masalah penelitian. Penentuan sampel menggunakan kriteria-kriteria tertentu sebagai berikut: Pertama, perusahaan-perusahaan dalam kelompok industri non keuangan. Hal ini ditetapkan karena perusahaan-perusahaan yang berada di dalam industri keuangan memiliki kebijakan dan regulasi yang berbeda. Kedua, perusahaan tercatat di BEI dan menerbitkan laporan keuangan. Keempat, Perusahaan memilki data mengenai kepemilikan manajerial, dewan komisaris independen, kepemilikan institusional dan menggunakan utang dalam membiayai operasinya selama periode penelitian. Jenis variabel dapat dibedakan pada variabel indenpenden dan variabel dependen. Variabel independen terdiri dari kepemilikan insitusional, kepemilikan manajerial, leverage dan komisaris independen, sedangkan variabel dependen adalah kinerja perusahaan yang dinalai menggunakan empat perspektif balance scorecard. 
Metode analisis data dilakukan dengan regresi data panel dalam melakukan uji regresi digunakan pengujian regresi dengan data panel, dengan melakukan pengelompokan data berdasarkan perusahaan selama periode 2008-2011. Dalam pengujian regresi data panel dapat digunakan dua metode yaitu fixed dan random. Untuk mengetahui metode mana yang tepat digunakan maka dalam pemilihan metode dilakukan uji Hausman. Pengujian hipotesis tentang pengaruh mekanisme GCG terhadap kinerja perusahaan digunakan dengan mengestimasi persamaan (1) sampai dengan persamaan (4).

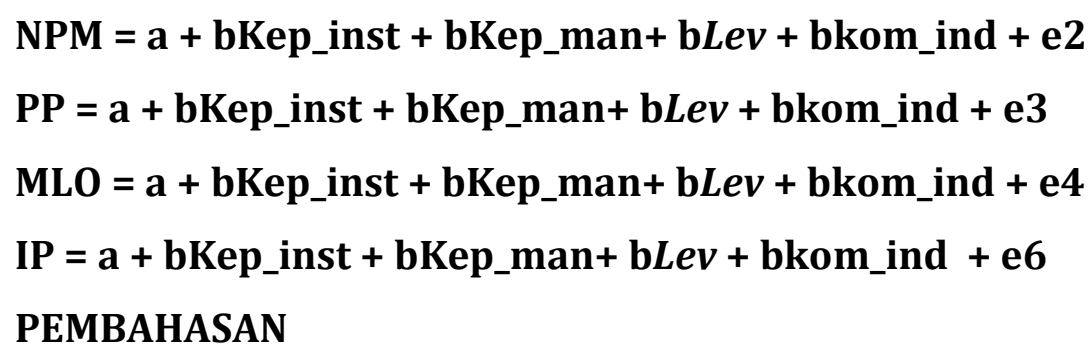

Berdasarkan hasil uji Hausman test menunjukan bahwa regresi panel cenderung menggunakan model fixed effect, hanya pada model 2 (dua) yaitu pengujian mekanisme GCG terhadap PP yang lebih tepat diestimasi dengan regresi panel metode random effect, sehingga Pembahasan akan berdasarkan hasil uji regresi berdasarkan metode yang digunakan pada masing-masing model. Pada bagian ini akan dibahas hasil uji regresi dengan data panel.

Berdasarkan hasil penelitian yang dilakukan, dapat disimpulkan bahwa tidak ada satupun mekanisme GCG berpengaruh secara signifikan terhadap NPM, dari model tersebut diketahui apabila tidak diterapkan mekanisme GCG maka nilai NPM sebesar - 0.0253 artinya perusahaan mengalami kerugian. Kepemilikan institusional memiliki koefisien - 0.0091 artinya jika bertambah kepemilikan institusional sebesar 1 maka NPM akan menurun sebesar 0.00091, sedangkan kepemilikan manajerial dengan koefisien 0.0198 menunjukan jika bertambah kepmilikan manajerial NPM akan bertambah sebesar 0.0198. Koefisien Leverage sebesar 0.1875 menunjukan bahwa jika lev bertambah maka NPM akan bertambah sebesar 0.1875, sementara itu koefisien -0.0011 pada komisaris independen menunjukan bahwa jika bertambah jumlah komisaris independen maka NPM akan berkurang sebesar koefisien tersebut. 
Mekanisme GCG yang berpengaruh secara signifikan terhadap PP adalah kepemilikan institusional, kepemilikan manajerial dan leverage. Akan tetapi kepemilikan institusional memiliki pengaruh negatif dengan koefisien 27.464 artinya jika bertambah kepemilikan institusional sebesar 1 maka PP akan menurun sebesar -27.464, sedangkan kepemilikan manajerial dengan koefisien 2.010 menunjukan bahwa jika bertambah kepemilikan manajerial maka PP akan bertambah sebesar 2.010. Koefisien leverage sebesar 0.4497 menunjukan bahwa jika utang bertambah maka PP akan meningkat sebesar 0.4497 , sementara itu koefisien 4.8766 pada komisaris independen menunjukan bahwa jika bertambah jumlah komisaris independen maka PP akan bertambah sebesar 4.8766 .

Mekanisme GCG yang berpengaruh secara signifikan terhadap MLO adalah kepemilikan institusional, kepemilikan manajerial dan leverage. Akan tetapi leverage memiliki pengaruh negatif dengan koefisien -0.0014 artinya jika bertamah leverage sebesar 1 maka MLO akan menurun sebesar - 0.0014, sedangkan kepemilikan manajerial dengan koefisien 0.1781 menunjukan bahwa jika bertambah kepemilikan manajerial maka MLO akan bertambah sebesar 0.1781. Koefisien kepemilikan insitusional sebesar 0.0631 menunjukan bahwa jika kepemilikan insitusional bertambah maka MLO akan meningkat sebesar 0.0631 , sementara itu koefisien -0.1165 pada komisaris independen menunjukan bahwa jika bertambah jumlah komisaris independen maka MLO akan turun sebesar 0.1165 , akan tetapi komisaris independen tidak berpengaruh secara signifikan.

Mekanisme GCG yang berpengaruh secara signifikan terhadap IP hanya leverage, akan tetapi pengaruhnya negatif , yaitu sebesar - 0.0964 yang berarti jika leverage bertambah maka IP akan menurun sebesar 0.0964. Mekanisme GCG lainnya yaitu kepemilikan institusional, kepemilikan manajerial dan komisaris independen tidak berpengaruh secara signifikan. Berdasarkan hasil uji regresi diperoleh hasil bahwa kepemilikan institusional cenderung memiliki pengaruh negatif pada 4 (empat) indikator kinerja yaitu NPM, PP dan IP, namun hanya pada satu indikator kinerja perusahaan, kepemilikan institusional 
berpengaruh negatif signifikan yaitu PP, sedangkan pada indikator MLO kepemilikan institusional berpengaruh positif dan signifikan.

Pada variabel kinerja perusahaan yang ditinjau dari perpektif pelanggan, menunjukan kepemilikan institusional berpengaruh negatif dan signifikan terhadap pertumbuhan penjualan dengan koefisien -27.4645 dan probabilitas 0.009. keadaan ini menunjukan adanya ekspropriasi yang dilakukan oleh pemegang saham insitusi, diduga produk-produk perusahaan dijual dengan harga yang lebih murah kepada perusahaan-perusahaan yang masih dalam grup perusahaanm menurut Bentuk dari ekspropriasi menurut Gilson dan Gordon (2003) dapat berupa menjual produk perusahaan dengan harga murah ke perusahaan lain yang ternyata milik manajer, serta manajemen laba untuk mengeruk keuntungan pribadi ataupun kelompok tertentu.

Kepemilikan institusional hanya berdapak positif dan signifikan terhadap MLO. Keadaan demikian sesungguhnya menunjukan adanya kemungkinan ekspropriasi oleh pemegang saham mayoritas yang dalam hal ini adalah kepemilikan institusional. Pengaruh positif kepemilikan institusional terhadap MLO yang merupakan indikator kinerja berdasarkan perspektif proses bisnis internal, menunjukan pihak mayoritas yaitu institusi tetap berupaya memperoleh laba dengan menekan biaya operasi perusahaan, karena itu keberadaannya berpengaruh positif kepada MLO. Fama dan Jensen (1980) menyatakan bahwa perusahaan dikontrol keluarga lebih efisien dibandingkan dengan perusahaan yang dijalankan professional.

MLO yang positif menandakan perusahaan beroperasi secara efisien, akan tetapi sebagai upaya meminimalkan pajak dan pembayaran dividen pihak institusi memberdayakan utang, sehingga laba bersih perusahaan menjadi lebih kecil. Pemberdayaan utang oleh pihak institusi dan pihak berelasi lainnya, terbukti dengan rata-rata leverage pada perusahaan yang diteliti berada pada tingkat diatas $100 \%$, yang berarti utang lebih besar membiayai aktifitas perusahaan dibandingkan modal sendiri. Utang yang besar tersebut berdampak negatif terhadap laba sebelum pajak sehingga dapat meminimalkan pembayaran pajak dan memperkecil laba bersih dengan tujuan 
tidak membagi dividen, ini terbukti dengan banyak perusahaan publik di Indonesia yang tidak membayar dividen dengan stabil.

Kepemilikan institusional sebenarnya dapat saja memberikan dampak positif kepada kinerja perusahaan secara keseluruhan, apabila institusi-institusi yang menjadi pemegang saham bukan berasal dari group perusahaan sehingga perannya sebagai kontrol bagi aktivitas perusahaan menjadi lebih independen.

Saat ini sebagaimana kita ketahui bahwa sebagaian besar institusiinstitusi yang menjadi pemegang saham di perusahaan merupakan group perusahaan dan mereka menjadi pemegang saham mayoritas, hal ini juga dinyatakan oleh (La Porta et. al., 1999; Claessens et. al., 2000a; Faccio dan Lang, 2002) bahwa fenomena berbagai perusahaan di Indonesia dikendalikan oleh pemegang saham pengendali yang sama adalah nyata, hal ini terjadi karena berbagai mekanisme kepemilikan khususnya kepemilikan piramida dan lintas kepemilikan lazim ditemukan dinegara berkembang termasuk indonesia.

Aktivitas moral hazard tersbut berupa tindakan menguntungkan kepentingan pribadi, yang dilakukan pihak keluarga. Aktivitas tersebut dapat berupa pembelian produk tertentu di perusahaan yang merupakan pemegang saham institusi dengan nilai relative diatas nilai pasar. Transaksi pihak berelasi akan memberi peluang bagi pemegang saham pengendali untuk mengambil alih kekayaan pemegang saham nonpengendali (tunneling) yang secara langsung mengekspropriasi pemegang saham nonpengendali.

Transaksi tersebut dilakukan antara lain melalui keputusan untuk membeli aset di atas harga pasar walaupun tidak ada nilai tambah strategis untuk operasi perusahaan (Henry \& Gordon, 2005). Kecurangan yang dilakukan pemegang saham institusi dengan pihak berelasi lainnya menyebabkan biaya di perusahaan membengkak dan mengurangi laba perusahaan.

Dengan keadaan seperti ini maka kepemilikan institusi yang merupakan pihak berelasi, tidak dapat berperan seperti yang di harapkan dalam stewardship theory, yaitu berperan sebagai pelayan yang melayani seluruh stakeholder perusahaan dengan meningkatkan kinerja sebagai upaya mencapai tujuan perusahaan, yaitu maksimalisasi kekayaan pemegang saham. 
Hasil penelitian ini berlawanan dengan penelitian sebelumnya yang dilakukan oleh Cornett et.al (2005); Fazlzadeh (2011); dan Gurbuz et.al (2010) yang menyatakan bahwa terdapat pengaruh signifikan kepemilikan institusional terhadap kinerja perusahaan. Penelitian ini memiliki hasil yang sama dengan penelitian Mokhtar et.al (2009) dan Wulandari (2006) yang menemukan bahwa tidak ada pengaruh signifikan mekanisme GCG terhadap Kinerja perusahaan. Penelitian yang dilakukan Moktar dan Wulandari dilakukan di Indonesia dan Malaysia yang memiliki karakteristik perusahaan hampir sama yaitu adanya konsentrasi kepemilikan saham yang umumnya dimiliki oleh keluarga. Penelitian-penelitian yang dilakukan Negara maju seperti Amerika, Jepang atupun Negara-negara Eropa seperti Inggris, Belanda dll, tentunya sebagian besar akan memiliki hasil yang berbeda, dengan hasil penelitian yang dilakukan di Indonesia, karena kondisinya berbeda.

Hasil regresi mekanisme GCG kepemilikan manajerial terhadap kinerja perusahaan di bagian ini, akan menjawab hipotesis 2.1 sampai dengan hipotesis 2.12. Sama halnya dengan kepemilikan institusional, kepemilikan manajerial merupakan mekanisme GCG yang mewakili stewardship theory.

Dalam penelitian ini ditemukan ada pengaruh positif signifikan kepemilikan manajerial terhadap kinerja yaitu pada indikator PP dan MLO, akan tetapi keberadaan kepemilikan manajerial belum mampu memberikan dampak signifikan terhadap kemampuan perusahaan dalam menghasilkan laba, hal ini terbukti dengan tidak adanya pengaruh signifikan terhadap NPM, serta kepada indikator lainnya yang terkait dengan laba bersih yaitu IP.

Hasil uji regresi pengaruh kepemilikan manajerial terhadap NPM sebagai kinerja perusahaan dalam perpektif keuangan menunjukan pengaruh yang tidak signifikan dengan probabilitas 0.0198 dan koefisien 0.3225. Menunjukan kepemilikan saham oleh manajer tidak berpengaruh terhadap efektifitas perusahaan dalam menghasilkan laba. Kepemilikan manajerial memiliki damapak positif dan signifikan pada PP dengan koefisien 2.0107 dan probabilitas 0.0000 , yang menunjukan manajer mampu memberikan dampak positif terhadap tumbuhnya penjualan perusahaan. 
Selain berpengaruh positif pada pertumbuhan penjualan kepemilikan kepemilikan manajerial juga berpengaruh positif pada dua variabel yang mewakili perspektif proses bisnis internal yaitu MLO. Keadaan demikian menunjukan mekanisme GCG yaitu kepemilikan manajerial belum berperan secara maksimal. Kepemilikan manajerial berpengaruh positif dan signifikan terhadap penjualan, agar dapat menutup beban operasional yang didalamnya termasuk imbalan berupa gaji dan bermacam tunujangan bagi para manajer, selain itu manajer tetap berusaha menaikan laba operasi sebagai ukuran keberhasilan kinerja manajer, akan tetapi sama halnya dengan kepemilikan insitusional berupaya menghindari pembagian dividen, dengan memutuskan penggunaan utang dalam operasional perusahaan dalam jumlah yang sangat besar, sehingga mengurangi laba bersih.

Tidak signifikannya pengaruh kepemilikan manajerial pada seluruh indikator kinerja perusahaan, disebabkan manajer-manajer yang memiliki saham perusahaan merupakan pihak keluarga ataupun pihak berelasi, yang lebih mementingkan kepentingan pribadi pihak kelaurga dan relasi, keberadaan mereka justru membuka peluang lebih besar terjadinya ekspropriasi terhadap pemegang saham minoritas.

Sebagai bagian dari pihak keluarga serta sebagai pengambil keputusan operasional perusahaan, bisa saja memutuskan membeli aset pada perusahaan tertentu yang merupakan grup keluarga dengan harga tinggi, ataupun mereka dapat memutuskan kompensasi yang diterima manajer perusahaan dan menetapkannya dengan nilai yang sangat besar, sehingga biaya yang dikeluarkan perusahaan menjadi sangat besar. Haggard et al. (2003) menyatakan bahwa masalah entrenchment juga dapat terjadi apabila keluarga selaku pendiri perusahaan (founder's family) memiliki kepemilikan saham yang kecil pada perusahaan induk, namun memiliki hak kendali yang cukup besar, sehingga dapat melakukan kendali terhadap anak perusahaan melalui kepemilikan sahamnya. Apabila anggota keluarga dari founder's family menduduki posisi sebagai pimpinan puncak, manajer dari founder's family memiliki hak kendali sehingga tidak mudah dikenakan sanksi disiplin. 
Hasil penelitian yang menunjukan tidak adanya pengaruh mekanisme kepemilikan manajerial pada hampir semua indikator kinerja, serta adanya pengaruh negatif dan signifikan kepemilikan manajerial terhadap kinerja berentangan dengan penelitian terdahulu yang dinyatakan oleh $\mathrm{Abu}$-Tapanjeh (2006); Kevin et.al (2004); Artini \& Sri (2008), dan Ernawati (2010) yang menyatakan terdapat pengaruh positif kepemilikan manajerial terhadap kinerja perusahaan.

Hasil penelitian memiliki hasil yang sama dengan penelitian ini adalah penelitian yang dilakukan Bos et.al (2011) dan Xianming Zhou (2001) yang menyatakan bahwa kepemilikan manajerial tidak berpengaruh terhadap kinerja perusahaan. Begitu juga dengan penelitian yang dilakukan oleh Chrisyine et.al (2012) pada perusahaan publik di Indonesia menemukan bahwa kepemilikan manajerial tidak berpengaruh terhadap kinerja perusahaan.

Leverage tidak berpengaruh secara signifikan terhadap kinerja perusahaan hampir pada seluruh indikator kinerja. Adanya leverage terhadap kinerja perusahaan sebenarnya justru cenderung berpengaruh negatif, terbukti pada penelitian ini ditemukan leverage berpengaruh negatif dan signifikan pada IP sebesar -0.098 dengan probabilitas 0.013. pengaruh negatif juga ditunjukan pada hasil uji pengaruh mekanisme GCG terhadap MLO dengan koefisien 0.0014 untuk MLO, hanya saja pengaruh keduanya tidak signifikan. pengaruh negatif leverage pada variabel yang terkait dengan laba menunjukan keberadaan leverage justru menurunkan kemampuan perusahaan dalam menghasilkan laba melalui proses operasinya. Sementara itu pengaruh leverage terhadap varibel NPM menunjukan pengaruh positif namun tidak signifikan

Tingginya jumlah utang diperusahaan menyebabkan laba bersih perusahaan mengalami penurunan, akibatnya mempengaruhi nilai IP yang dipengaruhi laba bersih, sehingga meskipun produktifitas karyawan mengalami peningkatan setiap tahunnya tetap tidak mampu meningkatkan laba bersih perusahaan. Selain berpengaruh pada IP, leverage juga berpengaruh pada PP. Berbeda dengan IP, pengaruh leverage pada PP bersifat positif dan signifikan sebesar 0.45 dengan probabilitas 0.000 . Pengaruh positif signifikan pada PP mengindikasikan perusahaan tetap berupaya meningkatkan penjualan agar 
mampu menutupi beban bunga yang muncul akibat penggunaan utang, Kenaikan utang proporsinya lebih banyak ditujukan untuk meningkatkan penjualan, agar memperoleh laba operasi yang besar sehingga mampu menutupi utang perusahaan.

Akan tetapi sayangnya keberadaan utang tidak mampu mempengaruhi perusahaan dalam menghasilkan laba bersih, keberadaan utang justru cenderung dimanfaatkan perusahaan untuk menghemat pembayaran pajak dan dividen, karena itu leverage cenderung berpengaruh negaif pada indikator kinerja yang terkait dengan laba besih. Penggunaan utang tinggi, dilakukan sebagai upaya untuk memperoleh keuntungan melalui penghematan pajak. Perhitungan besarnya pajak dilakukan setelah perhitungan beban bunga yang ditimbulkan akibat penggunaan utang, sehingga ketika utang tinggi beban bunga tinggi akibatnya pajak yang dibayarkan menjadi lebih kecil.

Fenomena utang diperusahaan-perusahaan Indonesia menimbulkan pertanyaan, mengapa utang di perusahaan sangat besar namun perusahaan seperti tidak banyak mngalami kendala, laba memang mengalami penurunan, namun dari faktor kinerja lainnya, kinerja perusahaan tergolong cukup baik, bahkan dari penelitian ini ditemukan meskipun ada pengaruh negatif utang terhadap kinerja perusahaan, namun pengaruh tersebut tidaklah signifikan pada kinerja non-keuangan. Ada dugaan banyak perusahaan di Indonesia memperoleh pinjaman dari grup perusahaan sehingga dengan begitu mereka bisa menghemat pajak , tanpa perlu khawatir terhadap risiko penggunaan utang berlebih yaitu mengalami kebangkrutan.

Kebijakan perbankan dalam pemberian kredit, juga menjadi penyebab dalam penggunaan utang perusahaan, banyak bank yang memberikan kredit tanpa memperhatikan jaminan yang diberikan perusahaan, bank hanya melihat grup perusahaan, karena itulah bermunculan kasus BLBI dalam dunia perbankan. Selain itu juga jika dilihat dari struktur pemegang saham perusahaan terdapat lembaga keuangan ataupun bank yang menjadi pemegang saham di perusahaan dengan porsi yang cukup besar, keadaan demikian memungkinkan perusahaan memperoleh aliran utang dari perusahaanperusahaan keuangan tersebut. 
Kwik (1994), mensinyalir perusahaan-perusahaan di Indonesia memakai trik-trik berisiko besar bagi bank dan investor di Bursa Efek Indonesia. Trik-trik tersebut merupakan perwujudan moral hazard yang dipraktekan untuk mengelabui bank dan investor terbuka. Sementara itu dari sisi bank kondisi dilematis terjadi. Keinginan bank untuk meningkatkan loan to deposit ratio berdampak pada non performing loan yang tinggi. Tekanan dari bank Indonesia dan pemerintah agar bank mengucurkan dana investasi ke sektor rill dan untuk menjaga kesehatan bank agar tidak mengandalkan keuntungan obligasi rekap, menyebabkan bank memberi pinjaman kepada perusahaan tanpa penyaringan jaminan anggunan yang memadai.

Adanya aliran dana dari perusahaan relasi tersebut membuat utang tidak mempengaruhi kinerja perusahaan secara keseluruhan, hal ini hanya berpengaruh pada kinerja keuangan perusahaan, namun kinerja perusahaan dari faktor non keuangan masih tetap baik karena aktivitas oprasional perusahaan tidak mengalami gangguan dari penggunaan utang yang besar. Hasil dari penelitian ini sejalan dengan yang dilakukan oleh Barucci dan Falini (2008) yang tidak berhasil menemukan adanya hubungan antara leverage dan kualitas implementasi corporate governance melalui pengukuran kinerja.

Berdasarkan hasil penelitian ditemukan keberadaan komisaris independen cenderung berpengaruh negatif terhadap kinerja perusahaan yaitu pada NPM MLO dan IP. Pengaruh komisaris independen terhadap PP bersifat positif namun tidak signifikan, hal ini menunjukan tidak ada pengaruh keberadaan komisaris independen dalam meningkatkan pertumbuhan penjualan dan pertumbuhan investasi pada aktiva tetap, guna menciptakan efektifitas dan efisiensi proses operasi Hasil penelitian tersebut menegaskan bahwa peran komisaris independen belum maksimal.

Tidak efektifnya dewan komisaris independen, dikarenakan komposisi dewan komisaris independen dalam komposisi dewan komisaris diperusahaan lebih sedikit, hal ini disebabkan biaya dewan komisaris sangat tinggi ini dibuktikan hasil penelitian Byrd tahun 1996 sampai dengan 1997 di Amerika menunjukan pada tahun 1996 pendapatan eksekutif dari perusahaan 42,6\% dan pada tahun 1997 44.15\% dari total seluruh pembayaran, hal ini tidak akan 
berbeda jauh dengan yang berlaku di Indonesia, ini didukung oleh bahwa pengungkapan gaji dan tunjangan direksi dan komisaris hanya diungkapkan pada level yang paling minimal bahkan semakin lama semakin banyak perusahaan yang tidak mengungkapkan, hal ini dilakukan karena tingginya biaya-biaya tersebut akan menimbulkan kecemburuan sosial diperusahaan sehingga berdampak negatif pada jalannya perusahaan

Untuk bisa memaksimalkan peran dewan komisaris independen, akan lebih baik lagi apabila diterapkan aturan seperti pada bank yang mengharuskan komposisi dewan komisaris independen adalah 50\% dari total dewan komisaris perusahaan, selain itu juga selain dari kredibilitas dewan komisaris independen yang harus ditingkatkan, perlu diterapkan kebijakan yang mengharuskan presiden komisaris tidak diperbolehkan memiliki hubungan keluarga dengan pemegang saham pengendali dan pihak eksekutif perusahaan.

Istilah good corporate governance (GCG) pertama kali diperkenalkan oleh Cadbury Committee tahun 1992 dalam laporannya yang dikenal sebagai Cadbury Report. Laporan ini dipandang sebagai titik balik yang sangat menentukan praktik GCG di seluruh dunia. Menurut Komite Cadbury dalam Daniri ( 2005) GCG adalah prinsip yang mengarahkan dan mengendalikan perusahaan agar mencapai keseimbangan antara kekuatan serta kewenangan perusahaan dalam memberikan pertanggungjawabannya kepada para shareholders khususnya, dan stakeholders pada umumnya. Dari definisi diatas dapat disimpulkan tata kelola perusahaan merupakan sistem ataupun pola hubungan antara organ perusahaan. Corporate governance juga merupakan struktur untuk mengarahkan dan mengendalikan kegiatan usaha perusahaan yang dilakukan manajemen untuk mencapai tujuan dari perusahaan melalui proses yang efektif dan efisien .

Dalam implementasinya GCG menggunakan mekanisme GCG Menurut Lukviarman (2002) sistem corporate governance sangat kompleks dan terintegrasi sehingga diperlukan suatu mekanisme kontrol. Mekanisme kontrol pada corporate governance dirancang untuk mengurangi ketidakefisienan kinerja manajemen perusahaan yang timbul karena moral hazard, kesalahan dalam pengambilan keputusan untuk mencapai tujuan perusahaan. Mekanisme 
GCG terdiri dari mekanisme internal dan eksternal, kedua mekanisme tersebut dalam penerapannya tidak dapat berdiri sendiri tetapi mekanisme-mekanisme tersebut saling menguatkan satu sama lain.

Berikut langkah-langkah penyelesaian permasalahan GCG di Indonesia: Pertama, untuk memaksimalkan peran komisaris independen, maka pengujian terhadap kredibilitasnya perlu diatur secara ketat, komisaris independen hendaknya adalah pihak yang dapat melindungi pemegang saham minoritas dan dipilih oleh pemegang saham minoritas bukan dari pemegang saham mayoritas. Dengan begitu peran dewan komisaris untuk melindungi kepentingan pemegang saham minoritas dapat berfungsi maksimal.

Kedua, berdasakan hasil penelitian diketahui utang perusahaan sangat besar karena itu untuk menghindarkan kerugian bank akibat penggunaan utang berlebih oleh perusahaan, maka harus ada pengawasan dari pemerintah terhadap pemberian kredit terhadap perusahaan agar tidak menimbulkan kerugian, pengawasan tersebut terutama yang berhubungan dengan jaminan, selain itu juga meskipun dalam undang-undang diatur mengenai hak-hak kreditur namun dalam perlu implementasi yang lebih baik dan diperlukan ketegasan dalam penerapannya. Ketiga, menambah dewan komisaris independen dalam komposisi dewan komisaris di perusahaan juga perlu dilakukan, tentunya dengan mempertimbangkan efisiensi perusahaan yang berhubungan dengan remunerasi (tunjangan-tunjangan), sehingga tidak menjadi beban yang berat bagi perusahaan. Saat ini aturan BAPEPAM mengenai komposisi komisaris independen diperusahaan hanya disyaratkan $30 \%$ dari seluruh dewan komisaris perusahaan, sementara keputusan yang diambil komisaris adalah keputusan bersama seluruh anggota jika jumlah dewan komisaris independen hanya 30\% sementara 70\% anggota komisaris lainnya merupakan pihak terafiliasi dengan pemegang saham mayoritas , maka komisaris independen akan kalah suara dalam menentukan kebijakan, hal ini terbukti dari hasil penelitian yang menunjukan bahwa komisaris independen tetap tidak bisa mempengaruhi manajemen dalam menentukan kebijakan dividen perusahaan. Keempat, Pada banyak perusahaan di Indonesia terjadi organ perusahaan pemegang saham pengendali (PSP), komisaris dan direksi 
melakukan rangkap jabatan, karena itu sebaiknya PSP , Komisaris dan Direksi sebaiknya merupakan pihak independen, yang tidak memiliki hubungan keluarga dengan pemegang saham pengendali. Sebaiknya komisaris, direksi dan pemegang saham pengendali tidak memiliki jabatan rangkap pada level eksekutif di perusahaan lain, hal ini ditujukan untuk menghindari penggunaan ataupun penyalahgunaan aset perusahaan untuk kepentingan bagi perusahaan lain. Kelima, dukungan pemerintah melalui regulasi untuk menerapkan GCG dan sanksi yang tegas, karena selama ini penerapan GCG di perusahaan hanya bersifat sukarela, selain itu juga perlu bagi lembaga-lembaga Negara untuk menerapkan GPG, karena GCG dapat berjalan dengan baik apabila GPG berjalan dengan baik, selama ini seperti telah dibahas sebelumnya tatakelola dilingkungan pemerintahan sendiri sangat tidak baik, sehingga sulit untuk menerapkan GCG secara maksimal, GCG dan GPG selalu berinteraksi. Selain dari pemerintah BAPEPAM ataupun otoritas jasa keuangan (OJK) sebagai lembaga yang mengatur dan mengawasi pasar modal perlu melakukan pengawasan yang lebih ketat terhadap penerapan GCG, namun pengawasan tersebut jangan sampai menimbulkan penurunan motivasi dunia usaha.

\section{SIMPULAN}

Berdasarkan hasil penelitian maka dapat disimpulkan baik mekanisme GCG yaitu kepemilikan insitusional, kepemilikan manajerial, leverage dan komisaris independen tidak mampu meningkatkan kinerja perusahaan, kecenderungan yang terjadi keberadaan kepemilikan insitusional dan manjerial tidak mampu meminimalkan ekspropriasi, namun justru menimbulkan ekspropriasi yang merugikan pemegang saham minoritas.

Langkah-langkah penyelesaian permasalahan GCG di Indonesia, ialah: pertama, komisaris independen hendaknya adalah pihak yang dapat melindungi pemegang saham minoritas dan dipilih oleh pemegang saham minoritas bukan dari pemegang saham mayoritas. Kedua, harus ada pengawasan dari pemerintah terhadap pemberian kredit terhadap perusahaan agar tidak menimbulkan kerugian. Ketiga, menambah dewan komisaris independen dalam komposisi dewan komisaris di perusahaan juga perlu dilakukan. Keempat, sebaiknya pemegang saham pengendali, Komisaris dan 
Direksi sebaiknya merupakan pihak independen, yang tidak memiliki hubungan keluarga dengan pemegang saham pengendali. Kelima, dukungan pemerintah melalui regulasi untuk menerapkan GCG dan sanksi yang tegas

\section{PUSTAKA ACUAN}

Claessens S, et.al. 2000. The Separation of Ownership and Control in East Asian Corporation. Journal of Financial Economics. Vol. 58 Iss. 1, 2, Oct/Nov. pp 81- 112 .

Claessens, S, et.al. 2002. Disentagling the Incentive and Entrenchment Effects of Large Shareholdings. Journal of Finance Vol. 57, No. 6: 2741-1771.

Clark, T. 2004. Theories of Corporate Governance: The Philosophical Foundations of Corporate Governance. London: Routledge.

Daily. C.M, et.al. 2003. Corporate Governance: Decades of Dialogue and Data. Academy of Management Review. Vol. 28.pp.371-382

Daniri. 2005. Good Corporate Governance : Konsep dan Penerapannya dalam Konteks Indonesia. Jakarta: PT Ray Indonesia.

Davis, J.H, et.al. 1997. Toward a Stewardship Theory of management. Academey of Management Review. Vol. 22.pp. 20-47

Jensen, M.C \& W.H. Meckling. 1976. Theory of the firm: managerial behavior, agency costs and ownership structure. Journal of Financial Economics 3. pp. 305-360.

Jensen, M.C \& J.B. Warner. 1988 . The Distribution of Power Among Corporate Managers, Shareholders and Directors. Journal of Financial Economics, Vol. 20. P 3-24

Kaplan, R.S., \& Norton, D.P. 1996. Menerapkan Strategi menjadi Aksi : Balance Scorecard. Terjemahan Peter R. Yosi Pasla . Jakarta: Erlangga.

Ross, W \& J. Jaffe. 2009. Modern Financial Management, 8th Edition. New York: McGraw-Hill, Inc.

Solomon, J., dan Solomon, A. 2004. Corporate Governance and Accountability. Jhon Wiley and Sons. Ltd. 